\title{
Effect of the Oxidative Phosphorylation Uncoupler Para-Nitrophenol on the Activated Sludge Community Structure and Performance of a Submerged Membrane Bioreactor
}

\author{
Ioannis Stavrakakis, Nikolaos Remmas, Paraschos Melidis and Spyridon Ntougias *(D) \\ Laboratory of Wastewater Management and Treatment Technologies, Department of Environmental Engineering, \\ Democritus University of Thrace, Vas. Sofias 12,67132 Xanthi, Greece; istavrak@env.duth.gr (I.S.); \\ nremmas@env.duth.gr (N.R.); pmelidis@env.duth.gr (P.M.) \\ * Correspondence: sntougia@env.duth.gr; Tel.: +30-254-107-9313
}

check for updates

Citation: Stavrakakis, I.; Remmas, N.; Melidis, P.; Ntougias, S. Effect of the Oxidative Phosphorylation

Uncoupler Para-Nitrophenol on the Activated Sludge Community Structure and Performance of a Submerged Membrane Bioreactor. Water 2021, 13, 3222. https: / / doi.org/10.3390/w13223222

Academic Editor: Laura Bulgariu

Received: 18 October 2021

Accepted: 11 November 2021

Published: 13 November 2021

Publisher's Note: MDPI stays neutral with regard to jurisdictional claims in published maps and institutional affiliations.

Copyright: (C) 2021 by the authors. Licensee MDPI, Basel, Switzerland. This article is an open access article distributed under the terms and conditions of the Creative Commons Attribution (CC BY) license (https:// creativecommons.org/licenses/by/ $4.0 /)$.

\begin{abstract}
In this work, the metabolic uncoupler para-nitrophenol (pNP) was applied to suppress excess sludge production and to investigate its effects on the system's performance and activated sludge community structure. The COD removal efficiency decreased from $99.0 \%$ to $89.5 \%$ prior to and after pNP addition, respectively. Application of pNP transiently reduced $\mathrm{NH}_{4}{ }^{+}-\mathrm{N}_{1} \mathrm{NO}_{3}{ }^{-}-\mathrm{N}$ and $\mathrm{NO}_{2}{ }^{-}-\mathrm{N}$ removal efficiencies, suggesting partial inhibition of both nitrifying and denitrifying activity. However, no changes in the relative abundance of the nitrifying bacteria occurred. Phosphorus removal efficiency was sharply reduced after pNP addition, as the consequence of hydrolysis of stored cell reserves. Tetrasphaera, a key polyphosphate accumulating organism, was also affected by the addition of pNP, a fact that highly influenced system's ability to remove phosphorus. A drastic drop in Soluble Microbial Products (SMP) and Extracellular Polymeric Substances (EPS) was also detected shortly after the introduction of the uncoupler. On the other hand, MBR's physicochemical parameters were restored to initial values a week after the addition of pNP. Moreover, remarkable changes in beta-diversity were noted after pNP addition. An increase of Bacteroidetes, Gammaproteobacteria and Firmicutes over Actinobacteria and Alphaproteobacteria was also observed after pNP addition.
\end{abstract}

Keywords: metabolic uncoupler; nitrophenols; excess sludge; nitrification and denitrification inhibition; Tetrasphaera

\section{Introduction}

Nowadays, activated sludge is the most recognized process in municipal and industrial wastewater treatment, due to its simplicity and high nutrient removal efficiency. However, activated sludge systems produce a high amount of excess sludge as a byproduct of the process [1]. In particular, excess sludge treatment is of high cost since it itself accounts for up to $60 \%$ of the total operating costs in biological nutrient removal systems, due to the stricter regulations for effluent disposal $[2,3]$.

As a result of the rising demand for upgraded water quality, membrane bioreactor (MBR) technology has become common for the treatment of municipal and industrial wastewater and nutrient recovery. An MBR is a modified activated sludge system, where the separation of solids is accomplished without using a secondary clarifier [4]. Main benefits of the MBR over the conventional activated sludge process include less excess sludge production and higher effluent quality. MBRs can operate under higher biosolids concentration than the conventional activated sludge systems, thus favoring a lower foodto-microorganism ratio and moreover, less sludge production [5]. Operation of MBR systems in the presence of chemical uncouplers is a challenging issue regarding sludge yield reduction. Recently, Ding et al. [6] focused on the effect of the chemical uncoupler 
$3,3^{\prime}, 4^{\prime}, 5$-tetrachlorosalicylanilide (TCS) on MBR operation, reporting low sludge production and EPS levels, a fact that improved membrane permeability.

Uncoupling metabolism is considered as an alternative method for treating excess sludge $[3,7,8]$. Specifically, reduction of excess sludge production can be achieved effectively by adding chemical uncouplers, without requiring any modification of the activated sludge process [3]. Unlike sludge pretreatment or sludge disintegration that lyse activated sludge microbiota, e.g., through thermal or chemical hydrolysis, metabolic uncouplers only partially dissociate catabolism from anabolism in microbial cells, resulting in reduced growth yield without causing cell death, while the substrate utilization rate is retained [9].

Metabolic uncouplers are compounds that stimulate the catabolic rather than the anabolic reactions in microorganisms. Most organic matter is oxidized to carbon dioxide rather than used in cell synthesis since adenosine triphosphate (ATP) synthesis is prevented in the presence of these compounds [10]. Uncoupling is defined as the chemiosmotic oxidative phosphorylation's inability to produce the full theoretical amount of metabolic energy in the form of ATP, which is often reported as "uncoupled oxidative phosphorylation" to distinguish from other uncoupling metabolism mechanisms. The energy binding between catabolism and anabolism is disassociated through metabolic uncoupling reduction. As a result, a portion of the energy derived from substrates is lost and anabolism energy supply is reduced, leading to restricted biomass production [11].

Organic protonophores, which transport protons across the intracellular cytoplasm membrane and thereby disperse the proton-motive driving force, effectively uncouple oxidative phosphorylation $[12,13]$. Chemical uncouplers may putatively be introduced to the wastewater treatment systems to dissociate activated sludge catabolism from anabolism, which has proved to be an effective way to restrict biomass production $[12,14]$. Among protonophores, nitrophenols have been used to minimize excess sludge production in activated sludge systems [15]. The main advantage of pNP is its high sludge reduction efficiency with little effect on COD removal. In particular, Wei et al. [16] listed that nitrophenols and especially pNP resulted in the highest sludge reduction among other protonophores. Moreover, Takdastan and Eslami [17] reported sludge reduction by $73-87 \%$ during the application of 120-130 mg/L pNP. Interestingly, Liu and Othman [18] recorded a less negative effect of pNP compared to TCS on COD removal efficiency. Low et al. [12] reported that addition of $120 \mathrm{mg} / \mathrm{L}$ para-nitrophenol ( $\mathrm{pNP}$ ) resulted in biomass reduction by $49 \%$. Zuriaga-Agustí et al. [10] also demonstrated that low pNP concentration $(25 \mathrm{mg} / \mathrm{L})$ had no adverse effect on activated sludge process, whereas $125 \mathrm{mg} / \mathrm{L} \mathrm{pNP}$ decreased sludge's activity by $29 \%$. Guo et al. [19] reported that addition of pNP as metabolic uncoupler could be easily degraded at reasonable concentrations, although even a small amount of such uncoupler can reduce biomass production. Moreover, Inglezakis et al. [20] stated that $8.5 \mathrm{mg} / \mathrm{L} \mathrm{pNP}$ resulted in low oxygen uptake rate inhibition $(<20 \%)$.

However, an in-depth understanding of activated sludge transition behavior regarding nutrients removal and microbial community structure in the presence of chemical uncouplers is crucial and requires further attention. In this work, the effects of pNP addition on the performance of an MBR system were examined by applying a thorough physicochemical analysis and an extended determination of proteinaceous and carbohydrate extracellular polymeric substances (EPS) and soluble microbial products (SMP) and by assessing the bacterial community structures prior to and after the uncoupler's addition via the implementation of high-throughput molecular techniques.

\section{Materials and Methods}

\subsection{Chemicals}

Anthrone, 4-nitrophenol (99\% purity) and N-(1-naphthyl)ethylenediamine dihydrochloride were purchased from Alfa Aesar (Tewksbury, MA, USA), $\mathrm{K}_{2} \mathrm{Cr}_{2} \mathrm{O}_{7}, \mathrm{Ag}_{2} \mathrm{SO}_{4}$ and $\mathrm{Na}_{2} \mathrm{~S}_{2} \mathrm{O}_{3} .5 \mathrm{H}_{2} \mathrm{O}$ from PanReac AppliChem, ITW Reagents Division (Barcelona, Spain), ferrous ammonium sulfate and $\mathrm{KH}_{2} \mathrm{PO}_{4}$ from PENTA Chemiclas (Prague, Czech Republic), coomassie brilliant blue and $\mathrm{FeSO}_{4} \cdot 7 \mathrm{H}_{2} \mathrm{O}$ from Fluka (Darmstadt, Germany) and ethanol 
from Fisher Scientific (Waltham, MA, USA). Moreover, ammonium molybdate, $\mathrm{NH}_{4} \mathrm{Cl}$ and $\mathrm{NaOH}$ were obtained from Lach-Ner (Neratovice, Czech Republic), $\mathrm{H}_{3} \mathrm{PO}_{4}, \mathrm{H}_{3} \mathrm{BO}_{3}$ and $\mathrm{CuSO}_{4}$ from CHEM-LAB (Zedelgem, Belgium) and $\mathrm{K}_{2} \mathrm{SO}_{4}$ and $\mathrm{H}_{2} \mathrm{SO}_{4}$ from VWR Chemicals (Radnor, PA, USA). The remaining reagents were purchased from MERCK (Darmstadt, Germany).

\subsection{Membrane Bioreactor Setup and Wastewater Composition}

A pilot-scale MBR was installed in the Laboratory of Wastewater Management and Treatment Technologies, Department of Environmental Engineering, Democritus University of Thrace, and operated under intermittent aeration and periodic feeding conditions. The MBR system consisted of a $12 \mathrm{~L}$ primary feeding tank and a main bioreactor of $24 \mathrm{~L}$ working volume, comprising of a hollow-fiber ultrafiltration membrane, operating under a hydraulic retention time (HRT) of 1 day (Figure 1). No sludge was removed from the bioreactor throughout the experimental period. Influent feed and effluent discharge were controlled by the use of two peristaltic pumps. Aeration was provided by an air pump, so that the dissolved oxygen concentration was maintained at $2.84 \pm 0.19 \mathrm{mg} / \mathrm{L}$. A submerged pump was used to admix activated sludge inside the main bioreactor. The unit was operated daily by performing two successive cycles of $12 \mathrm{~h}$ each, consisting of alternate anoxic/aerobic periods of $1 \mathrm{~h}$ each. Wastewater, consisting of $0.53 \mathrm{~mL}$ crude glycerol from biodiesel production/L, corresponding to $800 \mathrm{mg} / \mathrm{L} \mathrm{COD,} 76 \mathrm{mg} / \mathrm{L} \mathrm{NH}_{4} \mathrm{Cl}$ and $22 \mathrm{mg} / \mathrm{L} \mathrm{KH}_{2} \mathrm{PO}_{4}$, was used as the feed. The bioreactor was acclimatized for a period of 1 month without the addition of the metabolic uncoupler pNP. After biomass adaptation, $125 \mathrm{mg} / \mathrm{L} \mathrm{pNP}$ was daily introduced in the influent of the MBR. The application of this pNP concentration was selected on the basis that this was the maximum non-inhibitory concentration identified, resulting in high sludge reduction [17].

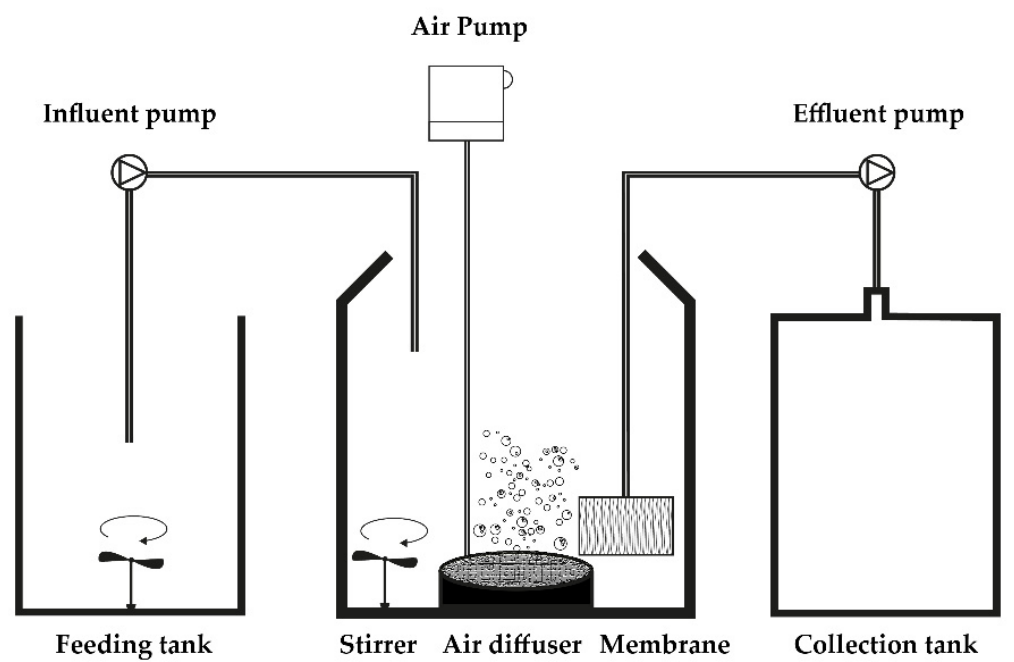

Figure 1. Schematic layout of the submerged membrane bioreactor.

\subsection{Estimation of Physicochemical Parameters}

Electrical conductivity (EC), $\mathrm{pH}$ and Chemical Oxygen Demand (COD) were measured 2-3 times weekly throughout the experimental period. In particular, EC and $\mathrm{pH}$ were determined by using a CM35 (Crison Instruments, Barcelona, Spain) and a HI98191 (Hanna Instruments, Woonsocket, RI, USA) probe, respectively. In particular, COD was measured after heating the samples at $150{ }^{\circ} \mathrm{C}$ for $2 \mathrm{~h}$ in the presence of $0.1 \mathrm{~N} \mathrm{~K}_{2} \mathrm{Cr}_{2} \mathrm{O}_{7}$ under strong acidic conditions and addition of $\mathrm{Ag}_{2} \mathrm{SO}_{4}$ as catalyst, whereas $\mathrm{HgSO}_{4}$ was added to diminish chlorides interference, followed by titration of excess amount of potassium dichromate with $0.02 \mathrm{~N}$ ammonium iron(II) sulfate solution in the presence of $25 \mathrm{mM}$ ferroin indicator [21]. Determination of 5 days-Biochemical Oxygen Demand $\left(\mathrm{BOD}_{5}\right)$ was manometrically determined in the presence of $\mathrm{KOH}$ trap and allylthiourea inhibitor [21]. 
Dissolved oxygen concentration was measured through the use of a Hanna HI764080 digital polarographic dissolved oxygen probe (Hanna Instruments, Woonsocket, RI, USA). Kjeldahl digestion followed by ammonia distillation was employed to assess Total Kjeldahl Nitrogen (TKN) and ammonia nitrogen $\left(\mathrm{NH}_{4}{ }^{+}-\mathrm{N}\right)$ content, respectively, while $\mathrm{NO}_{3}{ }^{-}-\mathrm{N}$ and $\mathrm{NO}_{2}{ }^{-}-\mathrm{N}$ concentrations were determined by reducing nitrate to nitrite in a column of copperized Cd granules and colorimetric estimation of nitrite concentration at $543 \mathrm{~nm}$ [21]. Orthophosphates were assessed through the reduction by a $2.5 \% w / v$ stannous chloride solution of the molybdophosphoric acid formed by the reaction orthophosphates with ammonium molybdate under acidic conditions [21]. Mixed liquor suspended solids (MLSS) and mixed liquor volatile suspended solids (MLVSS) were determined, according to Clesceri et al. [21].

\subsection{Determination of Soluble Microbial Products (SMP) and Extracellular Polymeric Substances (EPS)}

Regarding SMP and EPS, mixed liquor samples were collected and centrifuged at $3500 \mathrm{~g}$ for $15 \mathrm{~min}$, and the supernatant was filtered sequentially on $1.2 \mu \mathrm{m}$ and $0.45 \mu \mathrm{m}$ filters. The filtrate was used to determine the proteinaceous and carbohydrate content of SMP. For the determination of EPS, the centrifuged biomass of the mixed liquor was resuspended in an equal volume of a buffer solution [22]. After adding $10 \mathrm{~g} / \mathrm{g}$ MLVSS Dowex Marathon C (20-50 mesh, ion exchange resin, Sigma), the mixture was stirred for $2 \mathrm{~h}$, centrifuged at $4000 \mathrm{~g}$ for $15 \mathrm{~min}$ and successively filtered through $1.2 \mu \mathrm{m}$ and $0.45 \mu \mathrm{m}$ porosity filters. Protein and carbohydrate concentrations were determined by using the Bradford [23] protocol and the phenol-sulfuric acid method of Dubois et al. [24] to assess the respective proteinaceous and carbohydrate content of both SMP and EPS.

\subsection{Identification of Bacterial Communities}

Mixed liquor samples were subjected to DNA extraction by using the MachereyNagel's kit (Düren, Germany). Amplicons of the V4-V5 region of the 16S rRNA gene were obtained by using the Qiagen HotStarTaq Plus Master Mix Kit (Germantown, MD, USA) and the primer set new515F (5'-GTG YCA GCM GCC GCG GTA A-3') and 909R (5'-CCC CGY CAA TTC MTT TRA GT-3'). Amplification reaction included an initial denaturation stage of $3 \mathrm{~min}$ at $94{ }^{\circ} \mathrm{C}, 28$ amplification cycles of $30 \mathrm{~s}$ at $94^{\circ} \mathrm{C}, 40 \mathrm{~s}$ primer association at $53^{\circ} \mathrm{C}$ and DNA chain elongation at $72{ }^{\circ} \mathrm{C}$ for $1 \mathrm{~min}$, and a final DNA extension stage of $5 \mathrm{~min}$ at $72{ }^{\circ} \mathrm{C}$. Amplicons' purification was achieved through the use of Agencourt AMPure beads and Illumina reaction was carried out in a MiSeq instrument at "Mr DNA" sequencing facilities (USA). Unassembled, abnormal length size or lowquality and N(s)-containing reads were excluded. A total of 369,885 non-chimeric bacterial reads were uploaded to the NCBI database under the BioProject PRJNA770532. After demultiplexing and trimming, amplicons were improved in quality, clustered and tested for chimera using USEARCH v.11 [25]. Further, the MicrobiomeAnalyst web platform was employed to calculate alpha- and beta-diversity indices and to estimate correlation network matrices using the SparCC model at confidence level of 0.99 and probability of 0.01 [26]. Performance of Principal Coordinates Analysis (PCoA), through construction of a Bray-Curtis dissimilarity matrix and permutational multivariate analysis of variance (PERMANOVA), was employed to estimate beta-diversity indices. Analysis of variance (ANOVA) by employing Duncan's multiple tests was performed to identify significant differences among bacterial taxa.

\section{Results}

3.1. Effect of $p$ NP on Sludge Reduction, Nutrients Removal, Soluble Microbial Product (SMP) and Extracellular Polymeric Substances (EPS) during Operation of the MBR

The effects of the metabolic uncoupler pNP on sludge reduction and nutrients' removal were investigated by introducing pNP during the operation of an MBR without removing biomass from the system. Prior to pNP addition, activated sludge concentration was gradually increased from 2620 and $2200 \mathrm{mg} / \mathrm{L}$ to 6500 and $5650 \mathrm{mg} / \mathrm{L}$ MLSS and MLVSS, 
respectively (Figure 2a). A transient reduction in biosolids concentration was observed after pNP addition, resulting in MLSS and MLVSS content as low as 4070 and $3540 \mathrm{mg} / \mathrm{L}$, respectively (Figure 2a). A week afterwards, an increase in activated sludge concentration was observed, reaching values that exceeded $8000 \mathrm{mg} / \mathrm{L}$, indicating the adaptation of activated sludge microbiota to the selective pressure of pNP through either resistance or degradation (Figure 2a). Thus, the biological system restored its ability to synthesize biomass in a period of 7-HRTs after the introduction of the uncoupler.

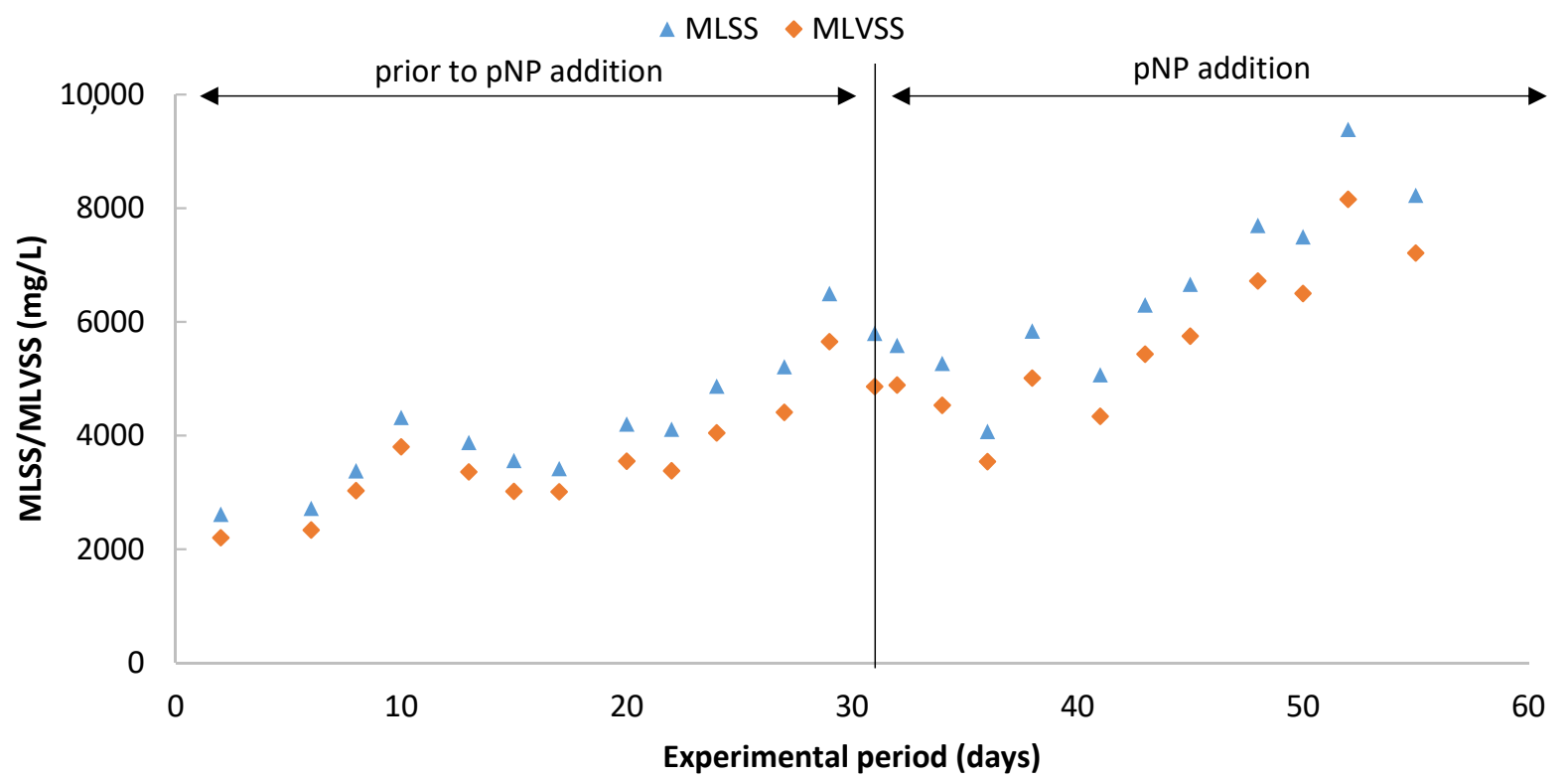

(a)

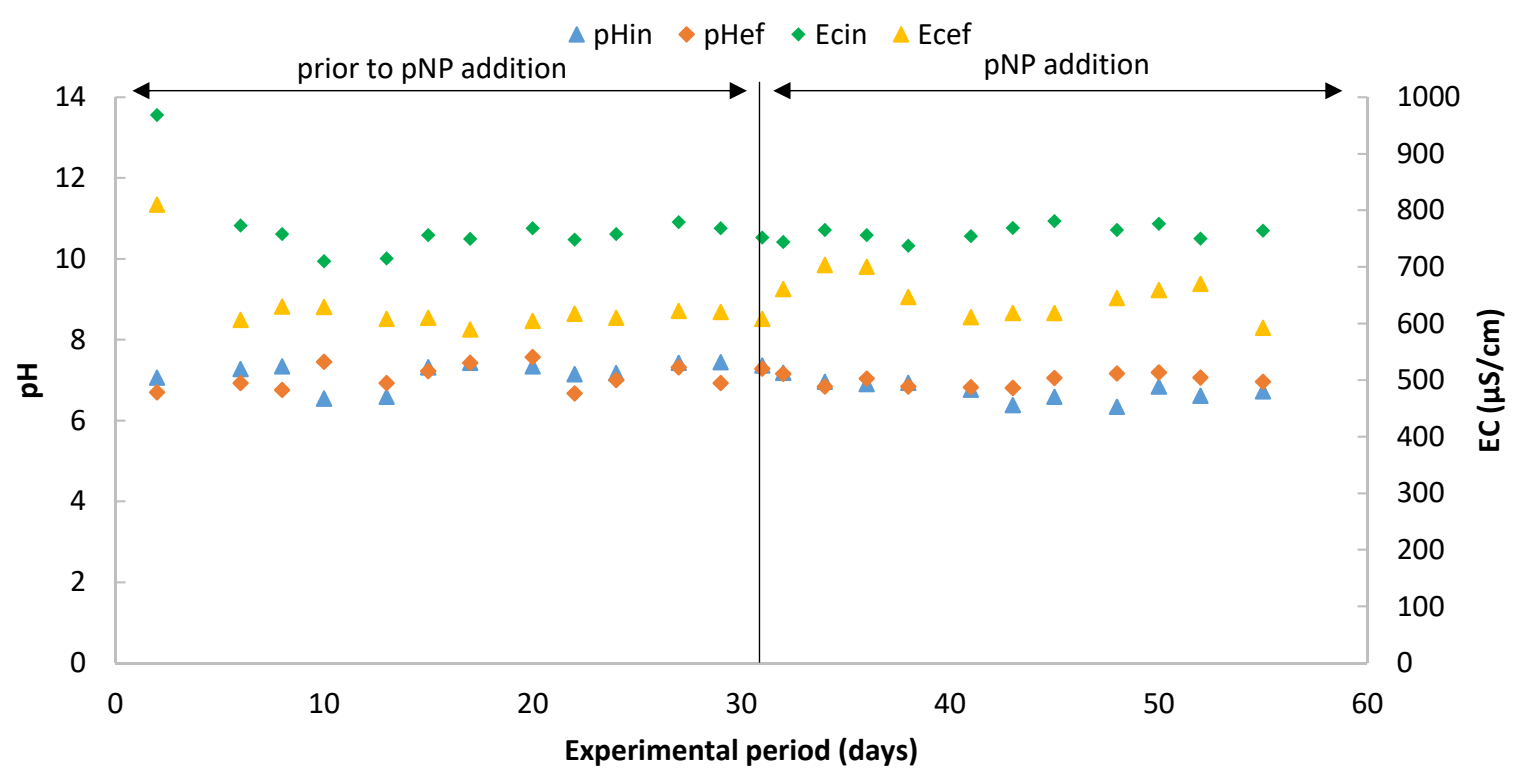

(b)

Figure 2. Effect of para-nitrophenol addition on (a) biosolids concentration and (b) $\mathrm{pH}$ and electrical conductivity (EC) profiles during operation of the MBR system.

No difference between influent and effluent $\mathrm{pH}$ was observed prior to $\mathrm{pNP}$ addition, with the respective values being equal to $7.18 \pm 0.08$ and $7.09 \pm 0.08$ (Figure 2b). However, $\mathrm{pNP}$ addition resulted in steadily higher $\mathrm{pH}$ values in the effluent compared to the influent $(p<0.05$, in Student's t-test) (Figure 2b). In contrast, effluent EC was always lower than influent EC prior to pNP addition $(p<0.01)$ (Figure $2 b)$. Moreover, $\mathrm{pNP}$ increased EC 
values from 608 to $703 \mu \mathrm{S} / \mathrm{cm}$ prior to and after the addition, indicating a disturb in metabolic processes, affecting the removal of ionic compounds (Figure $2 b$ ).

The COD removal efficiency was affected by the addition of pNP, causing a sharp increase in effluent COD concentration from $7.88 \pm 2.42 \mathrm{mg} / \mathrm{L}$ prior to $\mathrm{pNP}$ addition to $83 \mathrm{mg} / \mathrm{L}$ after the application of the uncoupler (Figure 3a). This corresponded to COD removal efficiency decrease from $99.0 \pm 0.3 \%$ to $89.5 \%$ prior to and immediately after the addition of pNP (Figure 3a). A drastic reduction of COD removal efficiency by $17 \%$ was also observed by Tian et al. [3] after the addition of the uncoupler 2,6-dichlorophenol. Furthermore, BOD concentration reduced from $628 \pm 12 \mathrm{mg} / \mathrm{L}$ in the influent to $3.9 \pm 1.4 \mathrm{mg} / \mathrm{L}$ in the effluent, with BOD removal efficiency being equal to $99.4 \pm 0.2 \%$ throughout the experimental process (Figure 3b). However, a slight increase in the effluent BOD concentration from 2 to $10 \mathrm{mg} / \mathrm{L}$ was observed by the introduction of $\mathrm{pNP}$ and up to 1 week afterwards.

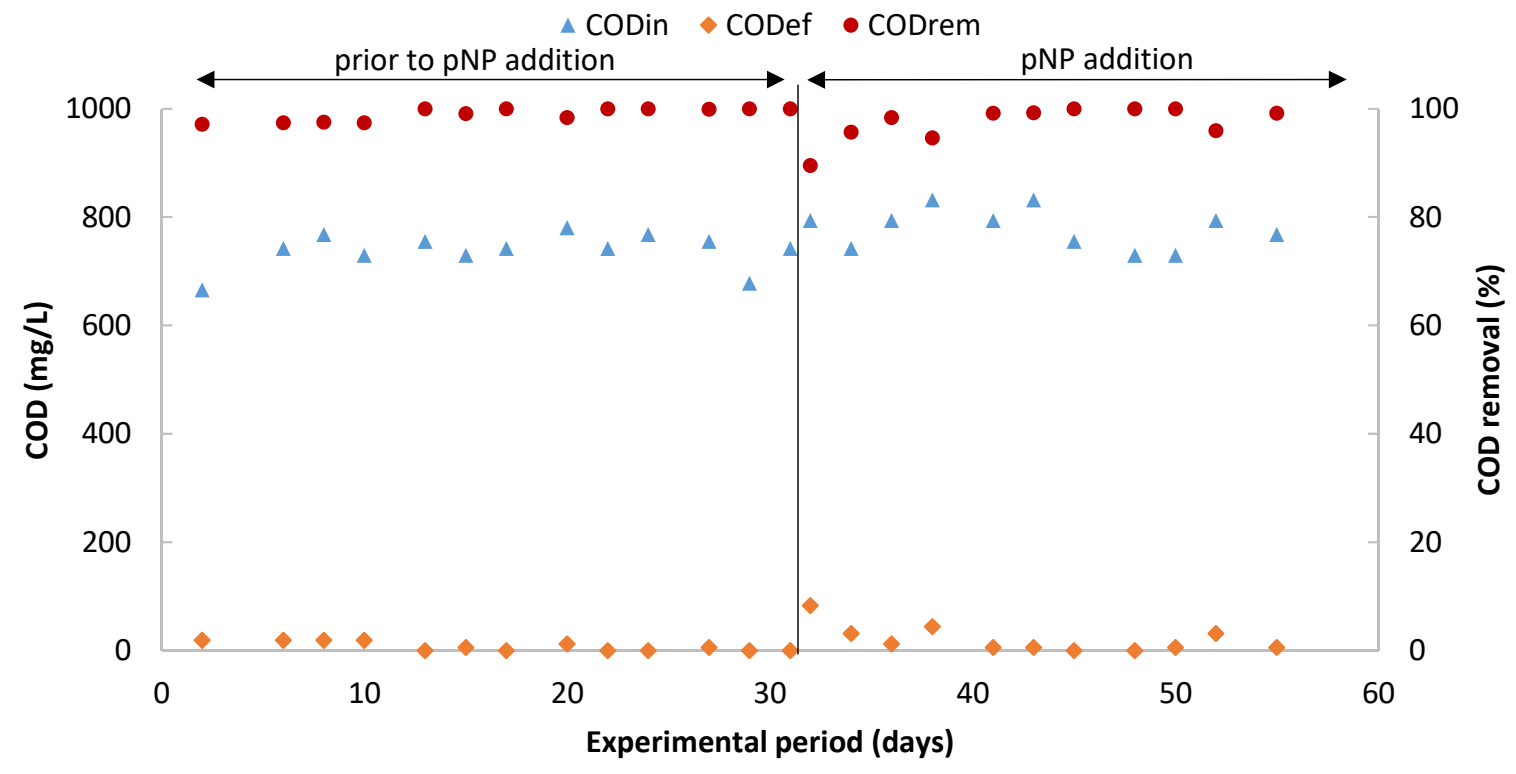

(a)

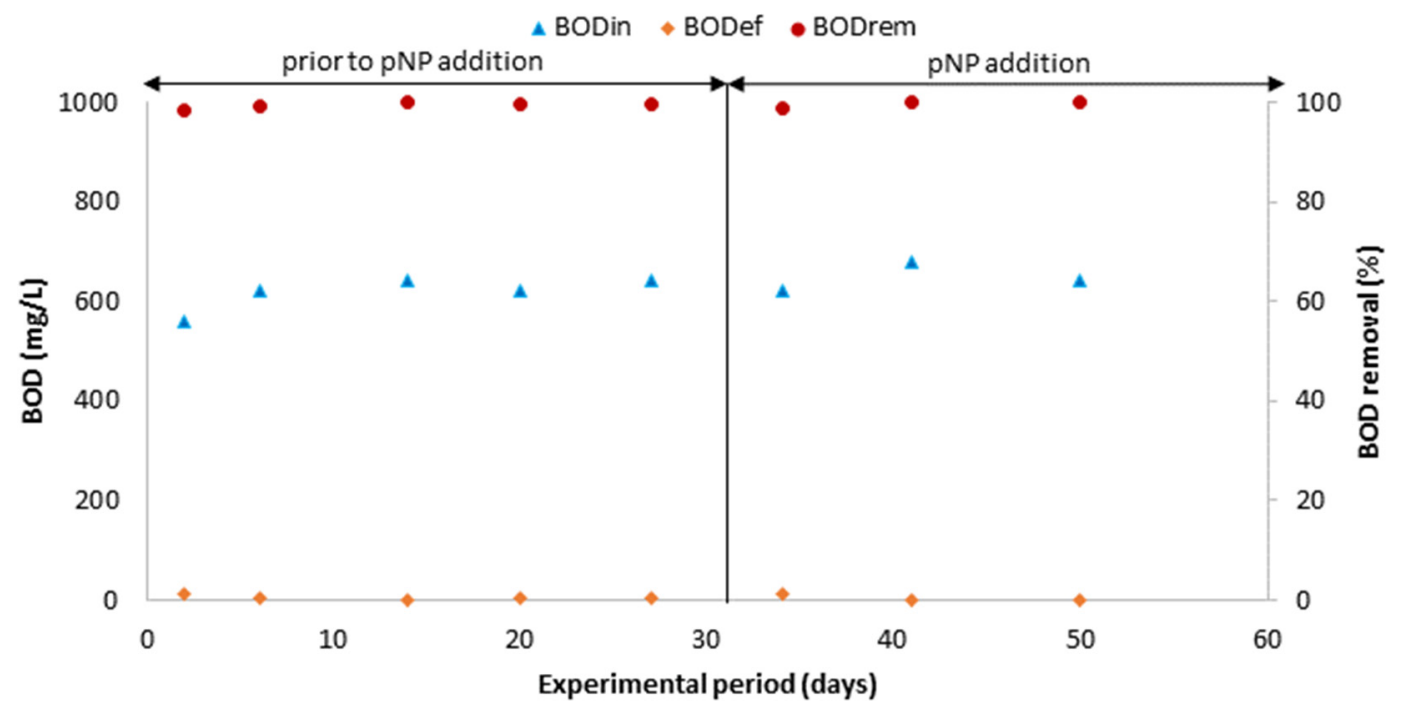

(b)

Figure 3. Effect of para-nitrophenol addition on (a) COD and (b) BOD removal efficiencies during operation of the MBR system. 
Prior to pNP addition, TKN and $\mathrm{NH}_{4}{ }^{+}-\mathrm{N}$ concentrations were significantly reduced from $20.1 \pm 0.3$ and $18.2 \pm 0.4 \mathrm{mg} / \mathrm{L}$ in the influent to $1.4 \pm 0.4$ and $0.5 \pm 0.1 \mathrm{mg} / \mathrm{L}$ in the effluent, respectively (Figure $4 \mathrm{a}$ ). However, by adding $\mathrm{pNP}$, effluent TKN and $\mathrm{NH}_{4}{ }^{+}-\mathrm{N}$ concentrations rose up to 9.8 and $8.4 \mathrm{mg} / \mathrm{L}$, respectively, indicating inhibition to some extent of the activity of ammonia-oxidizers, even though both effluent TKN and $\mathrm{NH}_{4}{ }^{+}-\mathrm{N}$ concentrations decreased 1 week afterwards, with the respective concentrations being below 0.8 and $0.5 \mathrm{mg} / \mathrm{L}$ (Figure 4a). However, effluent TKN remained unstable afterwards, fluctuating between 0.56 and $5.88 \mathrm{mg} / \mathrm{L}$. Ammonium accumulation was also observed by the addition of the uncoupler 2,6-dichlorophenol [3]. Moreover, $\mathrm{NO}_{3}{ }^{-}-\mathrm{N}_{\text {and }} \mathrm{NO}_{2}{ }^{-}$$\mathrm{N}$ concentrations increased after $\mathrm{pNP}$ addition from almost undetectable concentrations to 1.4 and $0.7 \mathrm{mg} / \mathrm{L}$, respectively (Figure $4 \mathrm{a}$ ). This may indicate transient deactivation not only of the nitrite-oxidizers, but also of the denitrifiers, a fact that denotes adverse effects of pNP on both autotrophic nitrifying and heterotrophic denitrifying communities. Li et al. [27] reported inhibition of denitrifying activity to some extent during the addition of $10 \mathrm{mg} / \mathrm{L}$ pNP. Moreover, Chen et al. [28] reported accumulation of nitrite and inhibition of nitrite reduction communities in a bioelectrochemical denitrification system in the presence of $100 \mathrm{mg} / \mathrm{L}$ pNP. Influent orthophosphate concentration was always higher than the respective effluent concentration prior to $\mathrm{pNP}$ addition $(p<0.01)$, determining influent and effluent values of $5.1 \pm 0.1$ and $1.4 \pm 0.2 \mathrm{mg} / \mathrm{L}$, respectively (Figure $4 \mathrm{~b}$ ). However, immediately after the addition of $\mathrm{pNP}$, effluent phosphate concentration rapidly elevated to $9.3 \mathrm{mg} / \mathrm{L}$, exceeding the influent concentration by $4.32 \mathrm{mg} / \mathrm{L}$, indicating P release from polyphosphate reserves of activated sludge (Figure $4 \mathrm{~b}$ ). A week after the addition of the uncoupler, effluent orthophosphate concentration was restored to the values prior to its introduction (Figure $4 \mathrm{~b}$ ). The uncoupling of catabolic processes resulted in the hydrolysis of the intracellular polyphosphate, which is used as energy reserve and stored by certain activated sludge taxa [29]. Interestingly, Yang et al. [30] reported a gradual decline in phosphorus removal efficiency by elevating the concentration of metabolic uncoupler TCS. Moreover, by adding pNP during MBR operation, nitrification was inhibited, as stated by the increase in the $\mathrm{NH}_{4}{ }^{+}-\mathrm{N}$ concentration, a fact that alters the anoxic stage to anaerobic, creating oxic-anaerobic conditions. This possibly resulted in higher orthophosphates concentration in the effluent compared to the influent. Barnard and Steichen [31] reported that under such conditions, "generally, phosphorus is released to more than 4 times the total phosphorus in the influent, but plants have been successful at a release of 2.5 times the influent concentration".

Proteinaceous SMP were higher than the respective EPS prior to pNP addition, while a reversible trend was observed after the introduction of metabolic uncoupler (Figure 5a). Moreover, the content of SMP and EPS of protein nature decreased immediately after the pNP addition, whereas their concentrations were restored 1 week afterwards the introduction of the metabolic uncoupler (Figure 5a). On the other hand, after a period of sludge adaptation (first 2 weeks of operation), carbohydrate SMP were lower than carbohydrate EPS prior to pNP addition, whereas the opposite trend was observed after the introduction of the uncoupler (Figure 5b). In addition, a drastic drop in their content occurred immediately after the addition, indicating, as in the case of proteinaceous SMP and EPS, an intensive effect on cell synthesis (Figure 5b). Similar to our study, a sharp reduction in proteinaceous EPS was reported by Zhang et al. [32] at high concentrations of nitrophenols-NP (>100 mg/L 2-NP, >50 mg/L 4-NP and >10 mg/L 2,4-DNP). Moreover, Fang et al. [33] found a reduction in the content of SMP during the addition of the uncoupler of ortho-chlorophenol in an SBR, but not in that of EPS. However, in accordance to our study, both Feng et al. [34] and Lin et al. [35] reported that EPS secretion decreased in the addition of the uncoupler TCS. 


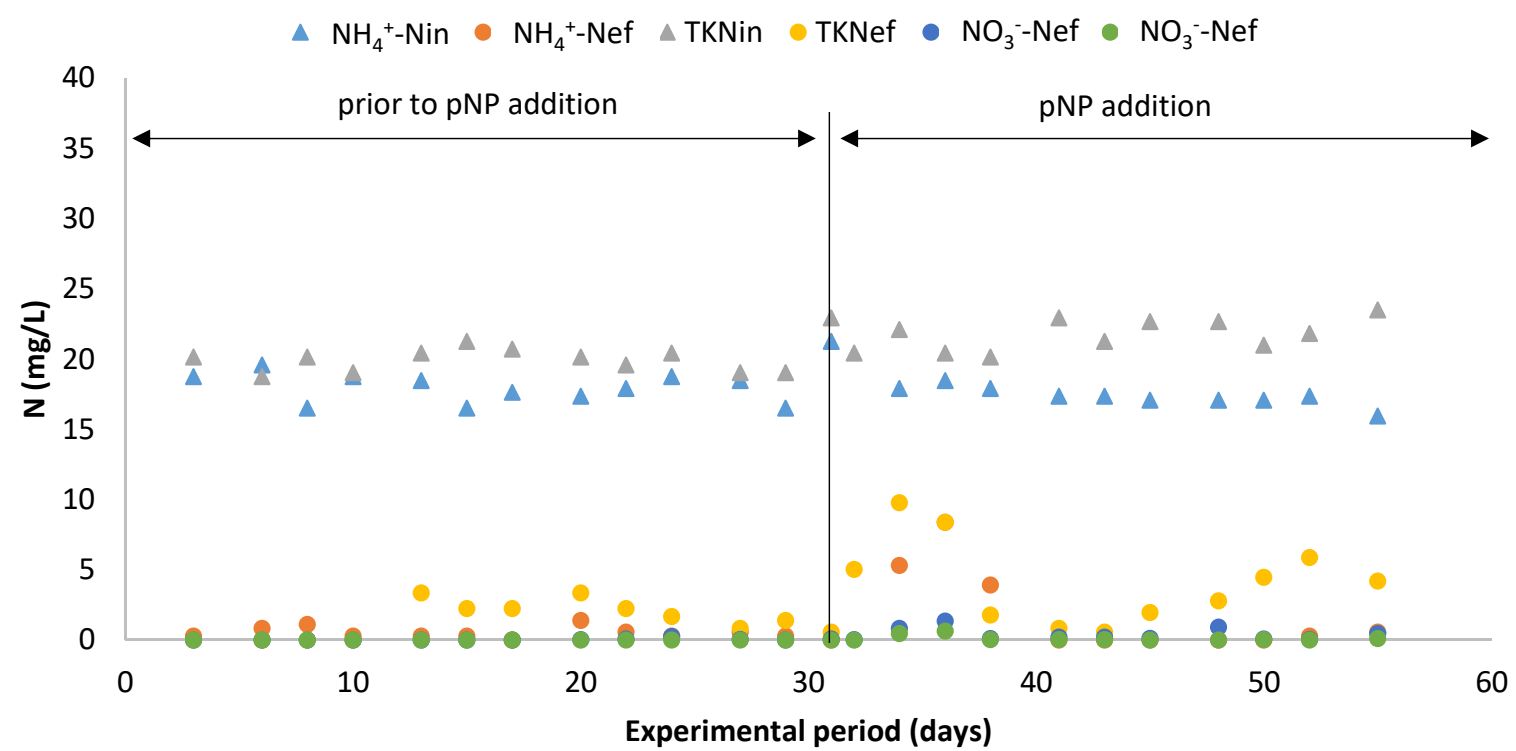

(a)

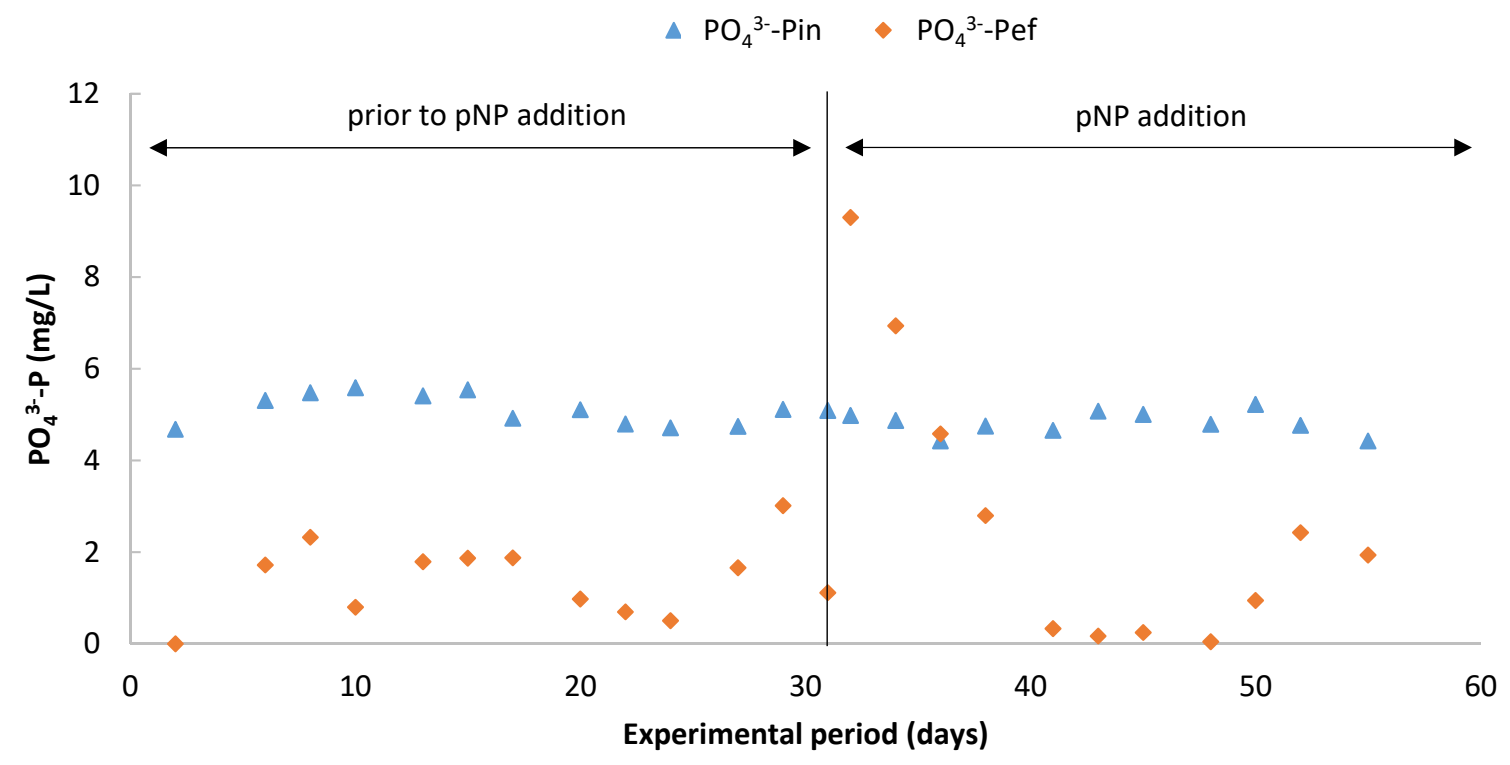

(b)

Figure 4. Effect of para-nitrophenol addition on (a) TKN, ammonium, nitrate and nitrite and (b) orthophosphate concentration profiles during operation of the MBR system.

As shown above, MBR's physicochemical parameters showed the tendency to restore to initial values 1 week after the application of pNP. Hiraishi and Kawagishi [36] reported complete recovery of biomass production rate after a short period from the addition of $200 \mu \mathrm{M} \mathrm{pNP}$, indicating that "dosing an uncoupler in a short period is useful for minimizing excess sludge production in the activated sludge process, but this positive effect is questionable over a long period of operation". Moreover, they found a remarkable change in respiratory quinone pattern, suggesting a shift in microbial community structure and an adaptation of activated sludge microbiota to the presence of $\mathrm{pNP}$. 


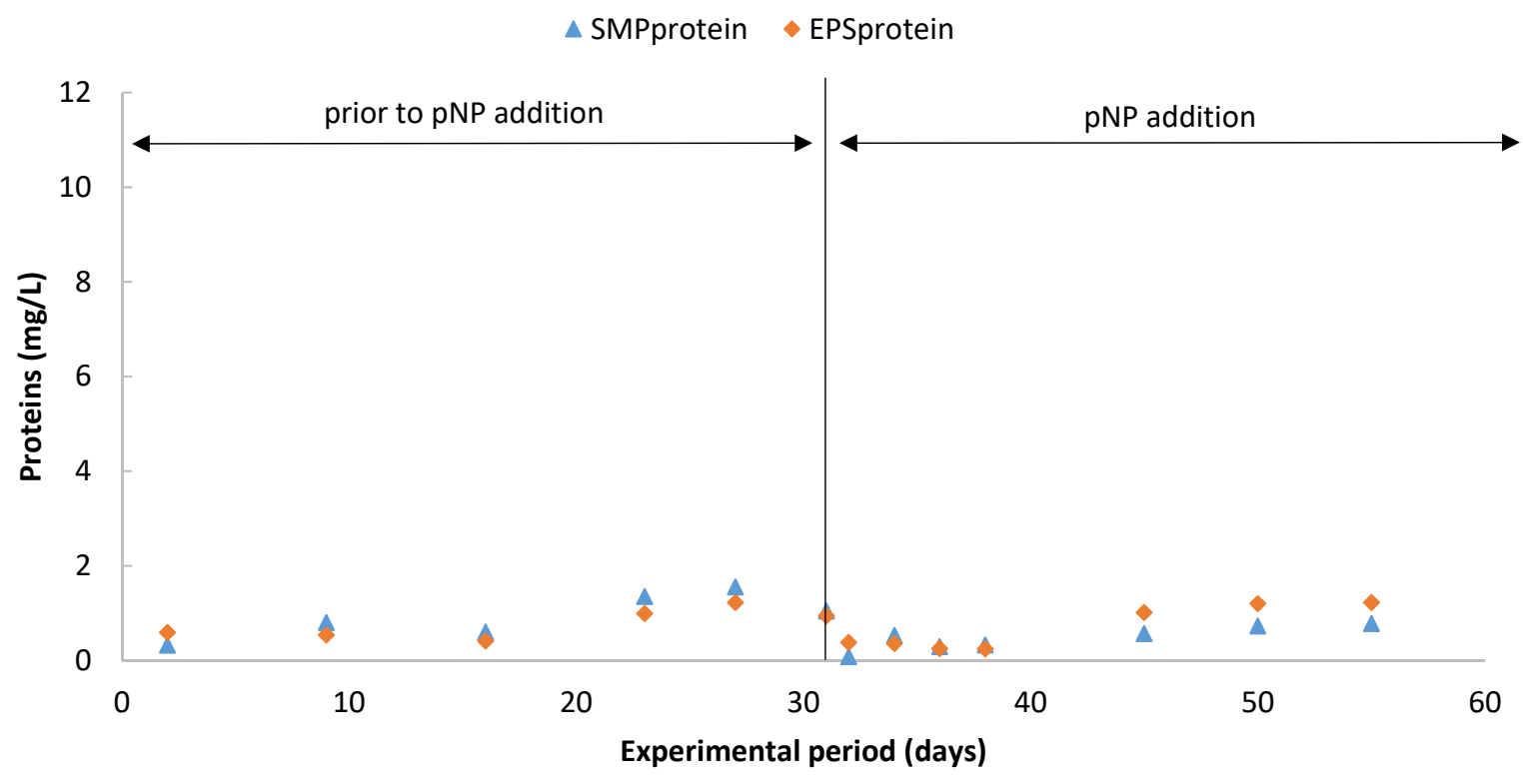

(a)

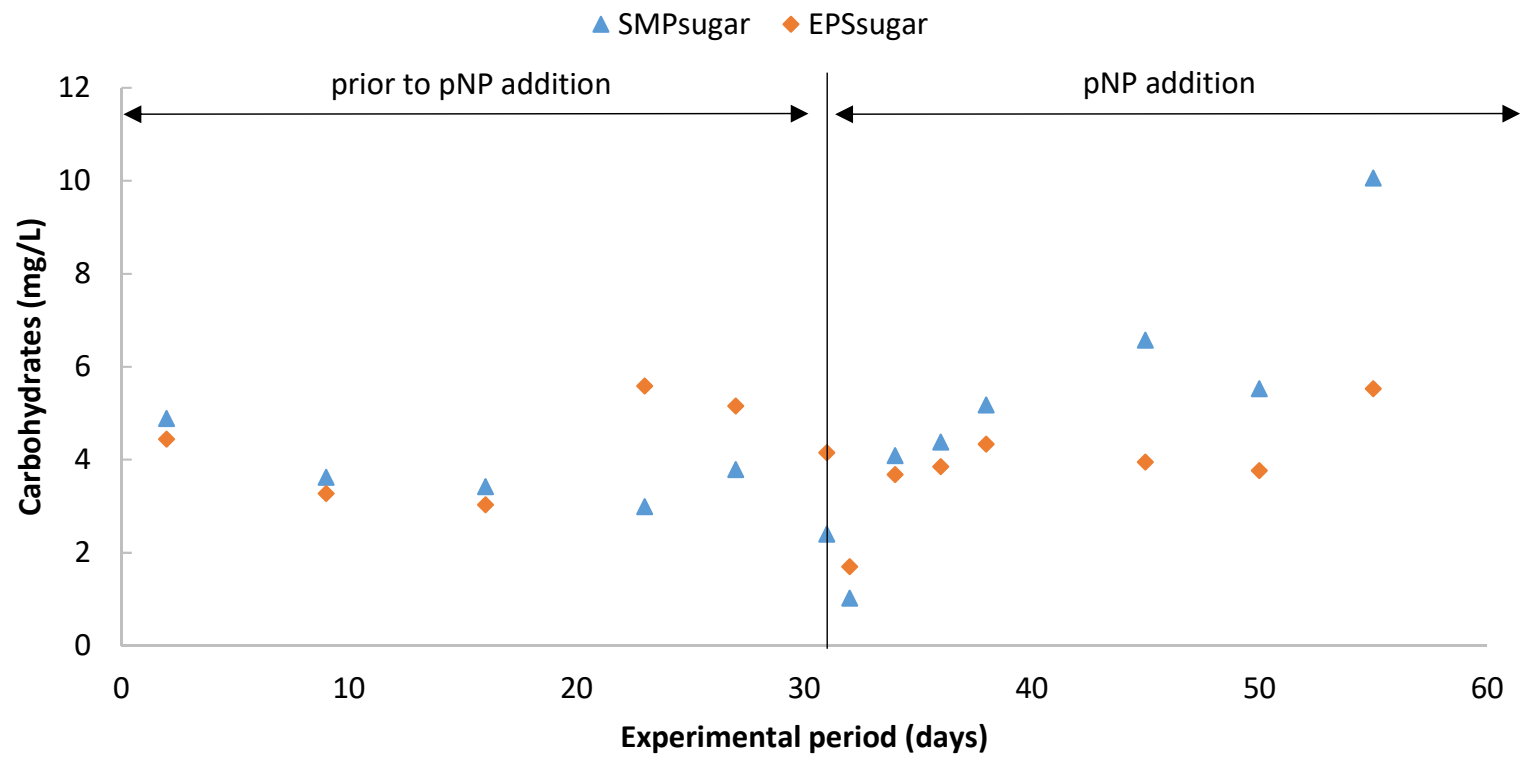

(b)

Figure 5. Effect of para-nitrophenol addition on (a) proteinaceous and (b) carbohydrate SMP and EPS concentrations during operation of the MBR system.

\subsection{Effect of $p N P$ on Bacterial Community Structure during Operation of the MBR}

At phylum-class level, Bacteroidetes, Actinobacteria, Betaproteobacteria, Planctomycetes and Alphaproteobacteria were the major taxa identified in the MBR throughout the experimental period (Figure 6a). However, a significant increase ( $p<0.05$, in Duncan's tests) in the relative abundance of Bacteroidetes, Gammaproteobacteria and Firmicutes over Actinobacteria and Alphaproteobacteria occurred immediately after the pNP addition (Figure 6a). Similar to our study, Ferrer-Polonio et al. [37] reported the dominance of Proteobacteria (all classes) in an SBR after the addition of the metabolic uncoupler TCS. These authors also reported an increase in the relative abundance of Gammaproteobacteria, although the opposite trend compared to this study was reported regarding Alphaproteobacteria. 


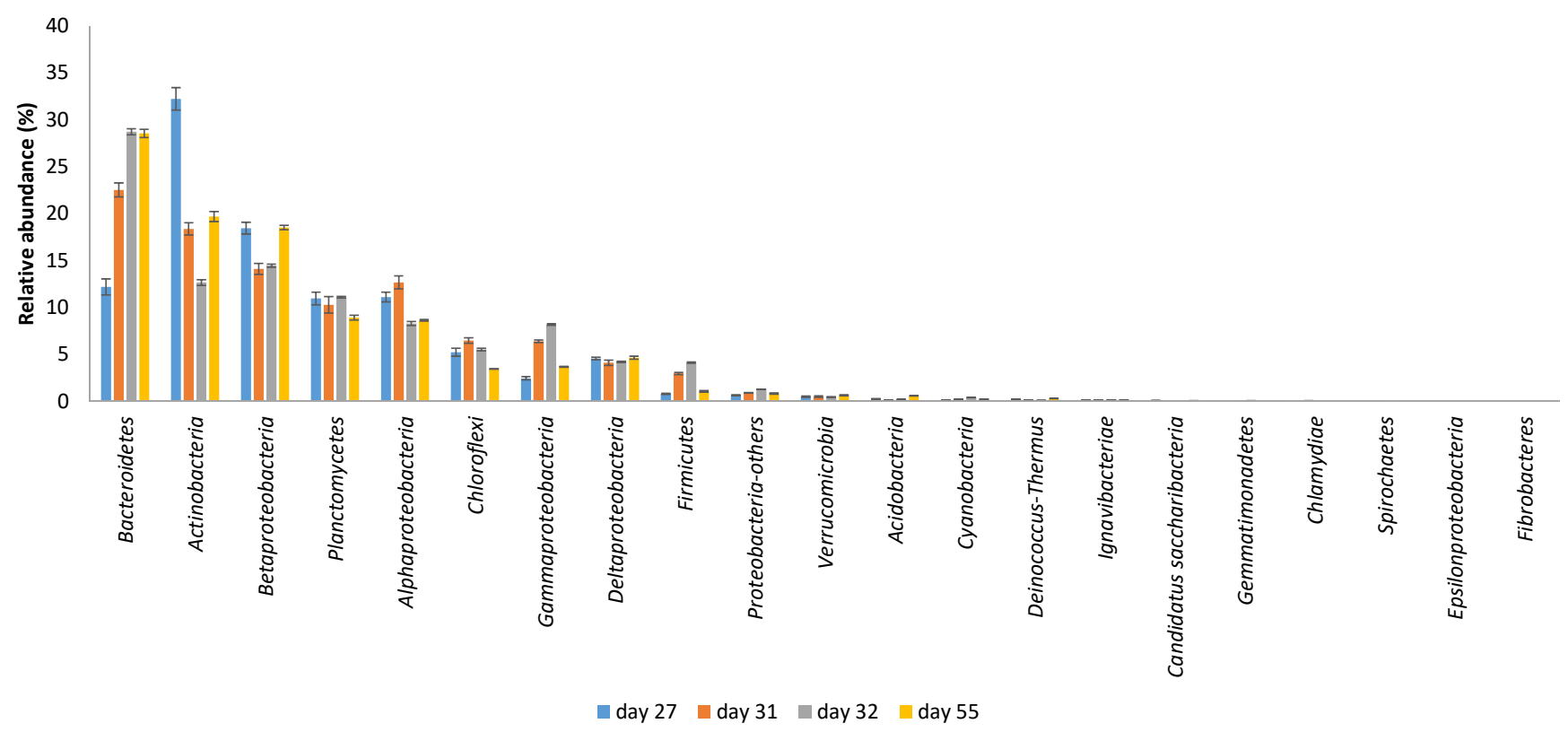

(a)

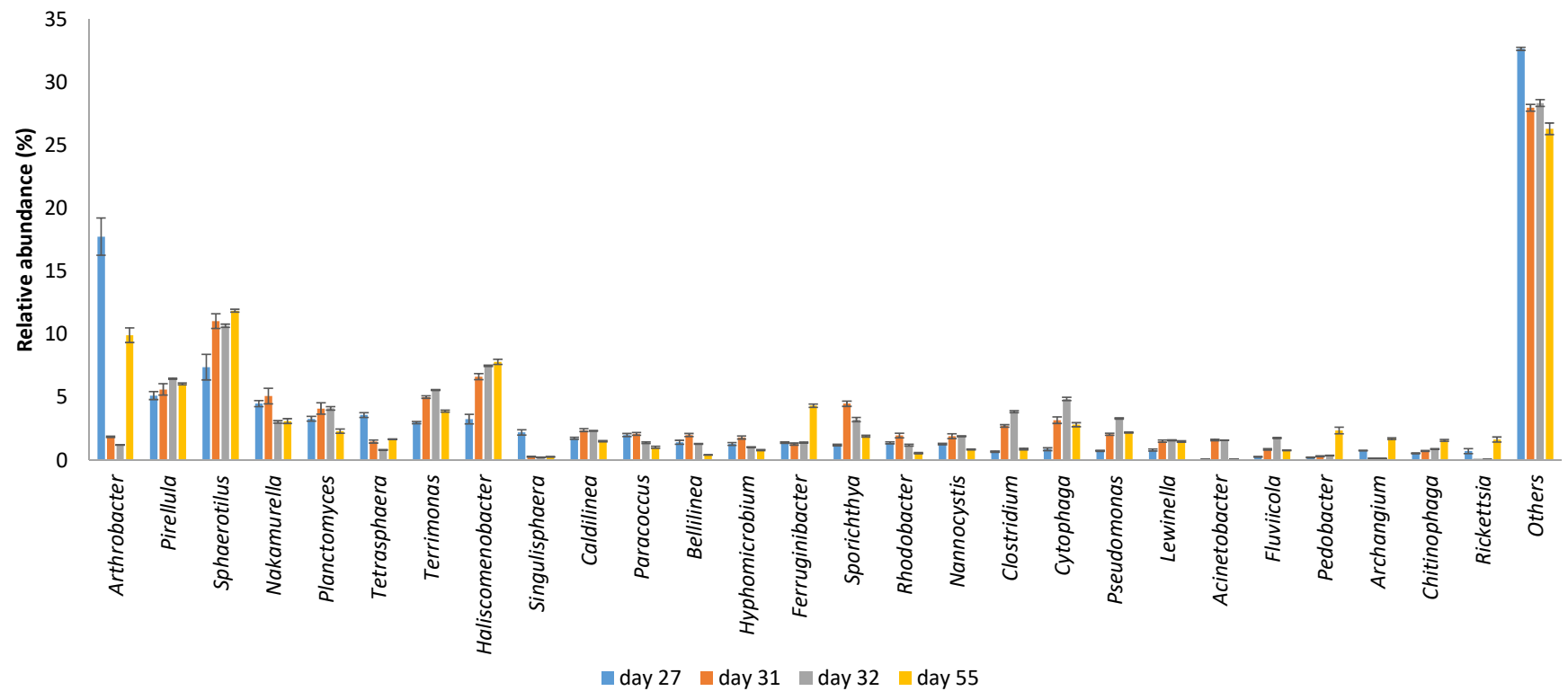

(b)

Figure 6. Effect of para-nitrophenol on activated sludge communities (a) at class-phylum and (b) genus level during operation of the MBR system prior to (days 27 and 31) and after (days 32 and 55) uncoupler's addition. Analysis of Variance (ANOVA) of the relative abundances of activated sludge taxa at phylum-class and genus level is presented in Tables S1 and S2, respectively.

At the genus level, the abundance of the major bacterial taxa Arthrobacter, Pirellula and Sphaerotilus was not affected by the addition of pNP and changes in the percentage of reads of these taxa could be attributed to activated sludge adaptation during startup (Figure $6 \mathrm{~b}$ ). Arthrobacter spp., as common constituents of activated sludge, are capable of utilizing high concentrations of pNP [38]. A decrease in the relative abundance of typical activated sludge microbiota, like Nakamurella, Paracoccus, Hyphomicrobium and Bellilinea, occurred after the pNP addition ( $p<0.05$, in Duncan's tests) (Figure 6b). Moreover, the relative abundance of Tetrasphaera, a putative polyphosphate accumulating organism (PAO) in enhanced biological phosphorus removal (EBPR) [39], was significantly reduced $(p<0.05)$ after the addition of the uncoupler. Tetrasphaera was affected by the addition of $\mathrm{pNP}$, 
resulting consequently in the hydrolysis of polyphosphate reserves of this taxon for energy gain and the release of orthophosphates. No Candidatus Accumulibacter phosphatis reads were detected throughout the experimental process, indicating that Tetrasphaera played the key role in phosphorus removal process in the MBR examined. On the other hand, bacteria with ability to degrade nitrophenols, such as Clostridium, Cytophaga, Pseudomonas, Fluviicola and Chitinophaga, thrived after pNP addition. Chen et al. [28] reported the proliferation of clostridia and pseudomonads in a bioelectrochemical denitrification system under prolonged application of pNP. Moreover, high occurrence of the filamentous bacteria Sphaerotilus and Haliscomenobacter was recorded throughout MBR operation, representing both $17.7-19.7 \%$ of the relative abundance at day 31 and afterwards. No statistically significant differences were identified in the relative abundance of nitrifying bacteria prior to and immediately after pNP introduction $(p=0.32)$, indicating that the abundance of nitrifiers was not affected by the addition of $\mathrm{pNP}$. However, this does not exclude the induction of adverse effects on their activity, as stated by the increase of effluent $\mathrm{NH}_{4}{ }^{+}-\mathrm{N}$ and $\mathrm{NO}_{2}{ }^{-}-\mathrm{N}$ concentrations.

Despite the statistically significant differences in Shannon and Simpson indicators, due to the pooled values determined, eventually no effect of pNP addition on alpha-diversity was observed (Table 1). However, remarkable changes in beta-diversity occurred after the addition of pNP (Figure 7a). In particular, the bacterial composition was similar prior to pNP addition, whereas distinct bacterial community structures were identified after the uncoupler addition (Figure 7a). Based on quinone profiling, Hiraishi and Kawagishi [36] reported a shift in microbial communities after the addition of $200 \mu \mathrm{M}$ pNP. Regarding strong relationships among activated sludge constituents, Arthrobacter, Terrimonas, Pseudomonas and Cytophaga were the key taxa of a solid network, where Runella and Byssovorax had a connecting role (Figure $7 \mathrm{~b}$ ).

Table 1. Estimation of alpha-diversity indices at various time-points prior to and after paranitrophenol addition during operation of the MBR system.

\begin{tabular}{ccccc}
\hline Index * & Day 27 & Day 31 & Day 32 & Day 55 \\
\hline Chao1 & $240.13 \pm 5.36(\mathrm{a})$ & $236.68 \pm 1.79(\mathrm{a})$ & $231.13 \pm 1.70(\mathrm{a})$ & $233.53 \pm 0.94(\mathrm{a})$ \\
\hline ACE & $235.91 \pm 2.20(\mathrm{a})$ & $234.13 \pm 2.64(\mathrm{a})$ & $230.89 \pm 1.93(\mathrm{a})$ & $233.54 \pm 1.39(\mathrm{a})$ \\
\hline Shannon & $3.90 \pm 0.03(\mathrm{ab})$ & $3.96 \pm 0.01(\mathrm{~b})$ & $3.96 \pm 0.01(\mathrm{~b})$ & $3.88 \pm 0.02(\mathrm{a})$ \\
\hline Simpson & $0.949 \pm 0.004(\mathrm{a})$ & $0.964 \pm 0.001(\mathrm{c})$ & $0.963 \pm 0.000(\mathrm{bc})$ & $0.956 \pm 0.001(\mathrm{~b})$ \\
\hline Fisher & $33.40 \pm 0.16(\mathrm{a})$ & $33.13 \pm 0.25(\mathrm{a})$ & $33.41 \pm 0.25(\mathrm{a})$ & $33.33 \pm 0.21(\mathrm{a})$ \\
\hline
\end{tabular}

*, Letters in common within rows indicate no statistically significant differences in alpha-diversity indices $(p<0.05$ in Duncan's tests).

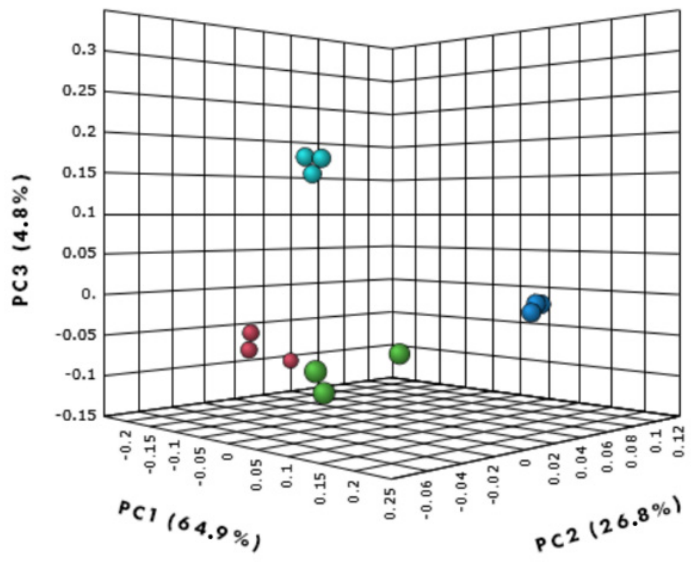

Figure 7. Cont. 


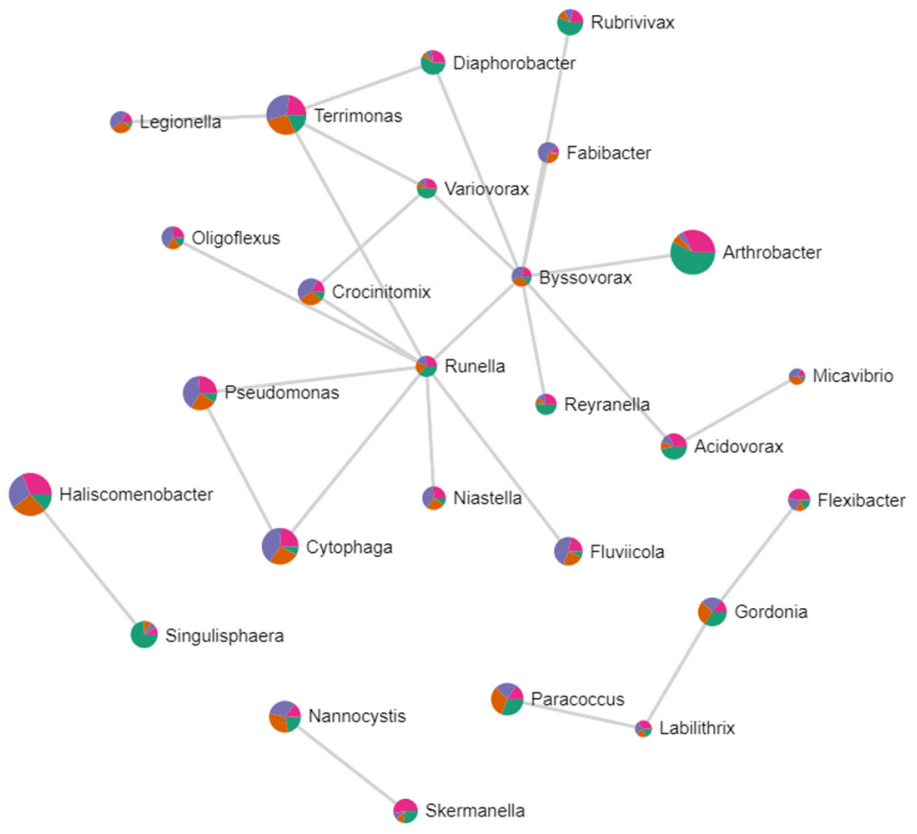

(b)

Figure 7. Schematic illustration of (a) beta-diversity based Principal Coordinates Analysis (PCoA) and (b) correlation network of activated sludge microbiota during operation of the MBR system prior to (days 27 and 31) and after (days 32 and 55) para-nitrophenol addition.

\section{Conclusions}

A drastic reduction of biomass production took place immediately after the addition of pNP. Application of pNP adversely affected MBR operation, by transiently reducing COD, $\mathrm{NH}_{4}{ }^{+}-\mathrm{N}, \mathrm{NO}_{3}{ }^{-}-\mathrm{N}$ and $\mathrm{NO}_{2}{ }^{-}-\mathrm{N}$ removal efficiencies, indicating partial inhibition of both nitrifying and denitrifying activity. However, the abundance of nitrifying bacteria was not influenced by the addition of pNP, although inhibition of their activity was demonstrated. An increase in orthophosphate concentration was determined in the mixed liquor of the MBR after pNP addition. On the other hand, MBR's physicochemical parameters showed the tendency to restore to initial values 1 week after the $\mathrm{pNP}$ addition. Addition of the metabolic uncoupler $\mathrm{pNP}$ had a significant effect on beta-diversity, indicating a remarkable change in bacterial community structure with the addition of the protonophore. In particular, an increase of Bacteroidetes, Gammaproteobacteria and Firmicutes over Actinobacteria and Alphaproteobacteria was observed immediately after the addition of pNP. A decrease in the abundance of typically activated sludge microbiota and proliferation of bacteria capable of degrading nitrophenols, such as Clostridium and Pseudomonas, was detected after the addition of the metabolic uncoupler. Tetrasphaera, a putative polyphosphate accumulating organism, was adversely affected by the addition of pNP, influencing the system's ability to remove phosphorus.

Supplementary Materials: The following are available online at https: / www.mdpi.com/article/ 10.3390/w13223222/s1, Table S1: Analysis of Variance (ANOVA) of the relative abundances of activated sludge taxa at class-phylum level during operation of an MBR system prior to and after para-nitrophenol addition; Table S2: Analysis of Variance (ANOVA) of the relative abundances of activated sludge taxa at genus level during operation of an MBR system prior to and after paranitrophenol addition. 
Author Contributions: Conceptualization, I.S. and S.N.; methodology, I.S.; formal analysis, I.S.; investigation, I.S.; data curation, I.S.; writing-original draft preparation, I.S.; writing-review and editing, I.S., N.R., P.M. and S.N.; visualization, I.S. and N.R.; supervision, S.N.; project administration, S.N.; funding acquisition, S.N. All authors have read and agreed to the published version of the manuscript.

Funding: This research was partially funded by ETAA's project KE-82257 “Investigation of methods for controlling sludge production in wastewater treatment systems".

Institutional Review Board Statement: Not applicable.

Informed Consent Statement: Not applicable.

Data Availability Statement: The data presented in this study are available upon request from the corresponding author.

Conflicts of Interest: The authors declare no conflict of interest.

\section{References}

1. Chon, D.-H.; Rome, M.; Kim, Y.M.; Park, K.Y.; Park, C. Investigation of the sludge reduction mechanism in the anaerobic side-stream reactor process using several control biological wastewater treatment processes. Water Res. 2011, 45, 6021-6029. [CrossRef]

2. Pérez-Elvira, S.I.; Diez, P.N.; Fdz-Polanco, F. Sludge minimisation technologies. Rev. Environ. Sci. Bio/Technol. 2006, 5, 375-398. [CrossRef]

3. Tian, Y.; Zhang, J.; Wu, D.; Li, Z.; Cui, Y. Distribution variation of a metabolic uncoupler, 2,6-dichlorophenol (2,6-DCP) in long-term sludge culture and their effects on sludge reduction and biological inhibition. Water Res. 2013, 47, 279-288. [CrossRef]

4. Ottoson, J.; Hansen, A.; Björlenius, B.; Norder, H.; Stenström, T.A. Removal of viruses, parasitic protozoa and microbial in-dicators in conventional and membrane processes in a wastewater pilot plant. Water Res. 2006, 40, 1449-1457. [CrossRef]

5. Fida, Z.; Price, W.E.; Pramanik, B.K.; Dhar, B.R.; Kumar, M.; Jiang, G.; Hai, F.I. Reduction of excess sludge production by membrane bioreactor coupled with anoxic side-stream reactors. J. Environ. Manag. 2021, 281, 111919. [CrossRef]

6. Ding, A.; Zhao, Y.; Ngo, H.H.; Bai, L.; Li, G.; Liang, H.; Ren, N.; Nan, J. Metabolic uncoupler, 3,3' , 4',5-tetrachlorosalicylanilide addition for sludge reduction and fouling control in a gravity-driven membrane bioreactor. Front. Environ. Sci. Eng. 2020, 14, 1-12. [CrossRef]

7. Yang, S.-S.; Guo, W.-Q.; Chen, Y.-D.; Wu, Q.-L.; Luo, H.-C.; Peng, S.-M.; Zheng, H.-S.; Feng, X.-C.; Zhou, X.; Ren, N.-Q. Economical evaluation of sludge reduction and characterization of effluent organic matter in an alternating aeration activated sludge system combining ozone/ultrasound pretreatment. Bioresour. Technol. 2015, 177, 194-203. [CrossRef] [PubMed]

8. Zhang, Q.; Hu, J.; Lee, D.-J.; Chang, Y.; Lee, Y.-J. Sludge treatment: Current research trends. Bioresour. Technol. 2017, $243,1159-1172$. [CrossRef] [PubMed]

9. Li, P.; Li, H.; Li, J.; Guo, X.; Liu, J.; Xiao, B. Evaluation of sludge reduction of three metabolic uncouplers in laboratory-scale anaerobic-anoxic-oxic process. Bioresour. Technol. 2016, 221, 31-36. [CrossRef]

10. Zuriaga-Agustí, E.; Mendoza-Roca, J.; Bes-Piá, A.; Alonso-Molina, J.; Amorós-Muñoz, I. Sludge reduction by uncoupling metabolism: SBR tests with para-nitrophenol and a commercial uncoupler. J. Environ. Manag. 2016, 182, 406-411. [CrossRef]

11. Fang, F.; Hu, H.-L.; Qin, M.-M.; Xue, Z.-X.; Cao, J.-S.; Hu, Z.-R. Effects of metabolic uncouplers on excess sludge reduction and microbial products of activated sludge. Bioresour. Technol. 2015, 185, 1-6. [CrossRef] [PubMed]

12. Low, E.W.; Chase, H.A.; Milner, M.G.; Curtis, T.P. Uncoupling of metabolism to reduce biomass production in the activated sludge process. Water Res. 2000, 34, 3204-3212. [CrossRef]

13. Liu, Y.; Tay, J.H. Strategy for minimization of excess sludge production from the activated sludge process. Biotechnol. Adv. 2001, 19, 97-107. [CrossRef]

14. Wang, Q.; Wei, W.; Gong, Y.; Yu, Q.J.; Li, Q.; Sun, J.; Yuan, Z. Technologies for reducing sludge production in wastewater treatment plants: State of the art. Sci. Total. Environ. 2017, 587-588, 510-521. [CrossRef]

15. Liu, Y. Chemically reduced excess sludge production in the activated sludge process. Chemosphere 2002, 50,1-7. [CrossRef]

16. Wei, Y.; Van Houten, R.T.; Borger, A.R.; Eikelboom, D.H.; Fan, Y. Minimization of excess sludge production for biological wastewater treatment. Water Res. 2003, 37, 4453-4467. [CrossRef]

17. Takdastan, A.; Eslami, A. Application of energy spilling mechanism by para-nitrophenol in biological excess sludge reduction in batch-activated sludge reactor. Int. J. Energy Environ. Eng. 2013, 4. [CrossRef]

18. Liu, Z.; Othman, M. Potential use of uncouplers to reduce activated sludge production. Int. J. Environ. Cult. Econ. Soc. Sustain. Annu. Rev. 2012, 7, 167-176. [CrossRef]

19. Guo, J.; Sims, A.; Gajaraj, S.; Wu, D.; Hu, Z. Effect of short-term exposure of selected aromatic nitrogen compounds on wastewater treatment. Water Environ. Res. 2014, 86, 2166-2175. [CrossRef] 
20. Inglezakis, V.J.; Malamis, S.; Omirkhan, A.; Nauruzbayeva, J.; Makhtayeva, Z.; Seidakhmetov, T.; Kudarova, A. Investigating the inhibitory effect of cyanide, phenol and 4-nitrophenol on the activated sludge process employed for the treatment of pe-troleum wastewater. J. Environ. Manag. 2017, 203, 825-830. [CrossRef]

21. Clesceri, L.; Greenberg, A.; Eaton, A. Standard Methods for the Examination of Water and Wastewater, 20th ed.; American Public Health Association (APHA): Washington, DC, USA, 1998.

22. Remmas, N.; Melidis, P.; Zerva, I.; Kristoffersen, J.B.; Nikolaki, S.; Tsiamis, G.; Ntougias, S. Dominance of candidate Saccharibacteria in a membrane bioreactor treating medium age landfill leachate: Effects of organic load on microbial communities, hydrolytic potential and extracellular polymeric substances. Bioresour. Technol. 2017, 238, 48-56. [CrossRef] [PubMed]

23. Bradford, M.M. A rapid and sensitive method for the quantitation of microgram quantities of protein utilizing the principle of protein-dye binding. Anal. Biochem. 1976, 72, 248-254. [CrossRef]

24. Dubois, M.; Gilles, K.A.; Hamilton, J.K.; Rebers, P.A.; Smith, F. Colorimetric method for determination of sugars and related substances. Anal. Chem. 1956, 28, 350-356. [CrossRef]

25. Edgar, R.C. UNOISE2: Improved error-correction for Illumina 16S and ITS amplicon sequencing. BioRxiv 2016, 081257.

26. Dhariwal, A.; Chong, J.; Habib, S.; King, I.L.; Agellon, L.B.; Xia, J. MicrobiomeAnalyst: A web-based tool for comprehensive statistical, visual and meta-analysis of microbiome data. Nucleic Acids Res. 2017, 45, W180-W188. [CrossRef]

27. Li, M.; Wei, D.; Yan, L.; Yang, Q.; Liu, L.; Xu, W.; Du, B.; Wang, Q.; Hou, H. Aerobic biodegradation of p-nitrophenol in a nitrifying sludge bioreactor: System performance, sludge property and microbial community shift. J. Environ. Manag. 2020, 265, 110542. [CrossRef]

28. Chen, D.; Yang, K.; Wei, L.; Wang, H. Microbial community and metabolism activity in a bioelectrochemical denitrification system under long-term presence of p-nitrophenol. Bioresour. Technol. 2016, 218, 189-195. [CrossRef]

29. Chudoba, P.; Morel, A.; Capdeville, B. The case of both energetic uncoupling and metabolic selection of microorganisms in the OSA activated sludge system. Environ. Technol. 1992, 13, 761-770. [CrossRef]

30. Yang, X.; Xu, X.; Wei, X.; Li, J.; Wan, J. Assessment of the sludge reduction of the metabolic uncoupler 3,3', $4^{\prime}, 5-$ tetrachlorosalicylanilide (TCS) in activated sludge culture. Int. J. Environ. Res. Public Health 2019, 16, 1686. [CrossRef]

31. Barnard, J.L.; Steichen, M.T. Optimizing BPR plant operations for achieving sustainable low effluent phosphorus. Proc. Water Environ. Fed. 2007, 2007, 903-926. [CrossRef]

32. Zhang, Z.; Yu, Y.; Xi, H.; Zhou, Y. Single and joint inhibitory effect of nitrophenols on activated sludge. J. Environ. Manag. 2021, 294, 112945. [CrossRef] [PubMed]

33. Fang, F.; Wang, S.N.; Li, K.Y.; Dong, J.Y.; Xu, R.Z.; Zhang, L.L.; Xie, W.-M.; Cao, J.S. Formation of microbial products by ac-tivated sludge in the presence of a metabolic uncoupler o-chlorophenol in long-term operated sequencing batch reactors. J. Hazard. Mater. 2020, 384, 121311. [CrossRef]

34. Feng, X.-C.; Guo, W.-Q.; Zheng, H.-S.; Wu, Q.-L.; Luo, H.-C.; Ren, N.-Q. Effect of metabolic uncoupler, 3,3',4',5tetrachlorosalicylanilide (TCS) on Bacillus subtilis: Biofilm formation, flocculability and surface characteristics. RSC Adv. 2018, 8, 16178-16186. [CrossRef]

35. Lin, W.; Ding, A.; Ngo, H.H.; Ren, Z.; Nan, J.; Li, G.; Ma, J. Effects of the metabolic uncoupler TCS on residual sludge treatment: Analyses of the microbial community and sludge dewaterability potential. Chemosphere 2021, 288, 132473. [CrossRef] [PubMed]

36. Hiraishi, A.; Kawagishi, T. Effects of chemical uncouplers on microbial biomass production, metabolic activity, and community structure in an activated sludge system. Microbes Environ. 2002, 17, 197-204. [CrossRef]

37. Ferrer-Polonio, E.; Fernández-Navarro, J.; Alonso-Molina, J.L.; Bes-Piá, A.; Amorós, I.; Mendoza-Roca, J.A. Changes in the process performance and microbial community by addition of the metabolic uncoupler $3,3^{\prime}, 4^{\prime}, 5$-tetrachlorosalicylanilide in sequencing batch reactors. Sci. Total Environ. 2019, 694, 133726. [CrossRef]

38. Li, Y.Y.; Zhou, B.; Li, W.; Peng, X.; Zhang, J.S.; Yan, Y.C. Mineralization of p-nitrophenol by a new isolate Arthrobacter sp. Y1. J. Environ. Sci. Health B 2008, 43, 692-697. [CrossRef]

39. Kristiansen, R.; Nguyen, H.T.T.; Saunders, A.M.; Nielsen, J.L.; Wimmer, R.; Le, V.Q.; McIlroy, S.J.; Petrovski, S.; Seviour, R.J.; Calteau, A.; et al. A metabolic model for members of the genus Tetrasphaera involved in enhanced bio-logical phosphorus removal. ISME J. 2013, 7, 543-554. [CrossRef] 